\title{
Venous ulcer: characterization of outpatient care at a university hospital
}

\section{Úlcera venosa: caracterização dos atendimentos em ambulatório de hospital universitário}

\section{Úlcera venosa: caracterización de la atención ambulatoria en un hospital universitário}

Aline Silva de Oliveira ${ }^{1 *}$, Débora Lira Correia², Karla Vanessa Pinto Vasconcelos², Saionara Leal Ferreira ${ }^{3}$, Francisca Alexandra Araújo da Silva³, Solange Gurgel Alexandre 3

ORCID IDS

Oliveira AS (D) https://orcid.org/0000-0003-0799-1719

Correia DL (D) https://orcid.org/0000-0001-5435-7759

Vasconcelos KVP (D) https://orcid.org/0000-0001-7851-4042

Ferreira SL (D) https://orcid.org/0000-0002-4131-7077

Silva FAA (D) https://orcid.org/0000-0001-6823-0193

Alexandre SG (D) https://orcid.org/0000-0001-6742-1043

\section{HOW TO CITE}

Oliveira AS; Correia DL; Vasconcelos KVP; Ferreira SL; Silva FAA; Alexandre SG. Venous ulcer: characterization of outpatient care at a university hospital. ESTIMA, Braz. J. Enterostomal Ther., 2020, 18: e2320. https://doi.org/10.30886/estima.v18.928_IN

\begin{abstract}
Objective: To characterize the clinical and sociodemographic profile of people with venous ulcers followed up in a specialized outpatient clinic of a university hospital. Method: documentary study carried out in a general surgery outpatient clinic of a university hospital. 104 instruments applied in the first nursing consultation were reviewed. Results: there was a predominance of females, with a mean age of 54 years. The majority did not perform paid work, the wound being the reason for leaving work activities. Systemic arterial hypertension and obesity were the most prevalent comorbidities. The person with venous ulcer was the main person involved in direct care of the wound. Conclusion: the profile of the study population is compatible with other studies in different contexts in Brazil. The results allow a reflection on the assistance provided and the effectiveness of the implemented interventions.
\end{abstract}

DESCRIPTORS: Varicose ulcer; Epidemiology; Health profile; Stomatherapy.

\footnotetext{
1. Universidade Estadual do Ceará - Departamento de Enfermagem - Fortaleza (CE), Brazil.

2. Universidade Federal do Ceará - Departamento de Enfermagem - Fortaleza (CE), Brazil.

3. Hospital Universitário Walter Cantídio - Ambulatório de Cirurgia - Fortaleza (CE), Brazil.

*Correspondence author: alinesoliveira312@gmail.com

Received: Jul. 25, 2020 | Accepted: Sep. 22, 2020
} 


\section{RESUMO}

Objetivo: caracterizar o perfil clínico e sociodemográfico de pessoas com úlceras venosas acompanhadas em ambulatório especializado de um hospital universitário. Método: estudo documental realizado em ambulatório de cirurgia geral de um hospital universitário. Realizou-se a revisão de 104 instrumentos aplicados na primeira consulta de enfermagem. Resultados: houve predominância do sexo feminino, com média de idade de 54 anos. A maioria não exercia atividade remunerada, sendo a ferida o motivo do afastamento das atividades laborais. A hipertensão arterial sistêmica e a obesidade foram as comorbidades mais prevalentes. A pessoa com úlcera venosa foi a principal envolvida no cuidado direto com a ferida. Conclusão: o perfil da população do estudo se mostra compatível com outros estudos em diferentes contextos do Brasil. Os resultados permitem uma reflexão acerca da assistência prestada e efetividade das intervenções implementadas.

DESCRITORES: Úlcera varicosa; Epidemiologia; Perfil de saúde; Estomaterapia.

\section{RESUMEN}

Objetivo: caracterizar el perfil clínico y sociodemográfico de las personas con úlceras venosas seguidas en una consulta externa especializada de un hospital universitario. Métodos: estudio documental realizado en una consulta externa de cirugía general de un hospital universitario. Se revisaron 104 instrumentos aplicados en la primera consulta de enfermería. Resultados: Predominó el sexo femenino, con una edad media de 54 años. La mayoría no realizó trabajo remunerado, siendo la herida la razón por la que dejó las actividades laborales. La hipertensión arterial sistémica y la obesidad fueron las comorbilidades más prevalentes. La persona con úlcera venosa fue la persona principal involucrada en el cuidado directo de la herida. Conclusión: El perfil de la población de estudio es compatible con otros estudios en diferentes contextos en Brasil. Los resultados permiten reflexionar sobre la asistencia brindada y la efectividad de las intervenciones implementadas.

DESCRIPTORES: Úlcera Varicosa; Epidemiología; Perfil de Salud; Estomaterapia.

\section{INTRODUCTION}

Ulcers of venous etiology are the most common ulcers of the lower limbs, accounting for approximately 80 to $90 \%$ of these wounds ${ }^{1}$.It is defined as an area of discontinuity of the epidermis that persists for four weeks or more and occurs as a result of venous hypertension and gastrocnemius muscle pump failure ${ }^{2}$.

Wounds arise spontaneously or traumatically, with the most frequent location being the malleolar region and the distal third of the leg. They can be single or multiple and of varying sizes. They are usually superficial, very exudative, and can be painful, an aspect that improves with elevation of the limbs ${ }^{3}$.

Venous ulcers (VU) are an old health condition and an important public health problem due to the negative impact on the quality of life of the person with the wound and the resulting increase in health expenses at the individual and governmental levels. Activities of daily living can be compromised due to pain, mobility difficulties and decreased productivity. This often results in removal from the work environment and disability pensions for people of working age.
Social relationships can also be affected, especially in individuals whose wounds have abundant exudation and odor, resulting in social isolation, low self-esteem and feeling of hopelessness regarding treatment ${ }^{4-6}$.

Due to the complexity of the wounds, their slow healing process and the consequent impact on quality of life, assistance to people with VU should be individualized and comprehensive. The care related to wound healing must be performed by a qualified professional who uses reasoning and clinical judgment to choose the appropriate treatment and monitoring the case, with the stomatherapist nurse being the outstanding professional for the practice, since they have different training concerning wounds.

Stomatherapy is an exclusive specialty of nurses, focused on the care of people with stomas, wounds and incontinence, in its preventive, therapeutic and rehabilitation aspects with a view to improving the quality of life ${ }^{7}$. The assistance of the stoma nurse is carried out through the nursing consultation guided by the Nursing Care Systematization (NCS).

The nursing consultation directed to the person with a chronic wound is configured as a light-hard technology 
of great relevance for the success of the treatment, as it proves effective for the detection of the self-care requirements, as well as the monitoring of the measures instituted individually and appropriate to the specific needs of each person. It also allows self-developing of skills to improve their quality of life ${ }^{8}$.

Due to the unavailability of an official estimate regarding the prevalence and incidence of $\mathrm{VU}$, its profile in the Brazilian population, as well as the nursing care provided to these people, the following question arose: what is the clinical and sociodemographic profile of people with VUs monitored in a specialized outpatient clinic of an university hospital?

\section{OBJECTIVE}

To characterize the clinical and sociodemographic profile of people with VU followed in a specialized outpatient clinic of a university hospital.

\section{METHOD}

Documentary study carried out in a specialized outpatient clinic of a university hospital in the city of Fortaleza - Ceará, which serves, among others, people with VUs.

The study population consisted of medical records of people with VUs, over 18 years of age, of both sexes, who were followed up from 2015 to 2018, in the referred clinic.

The inclusion criteria used were: a person with VU who performed the first nursing consultation with filling out an instrument used in the service as part of the NCS. People with ulcers of other etiologies, such as arterial or mixed (venous and arterial) were excluded.

A total of 312 people with injuries were identified, followed up at the referred outpatient clinic, and 184 instruments used in the first nursing consultations were found. Of these, 104 belonged to people with VU diagnoses, who met the inclusion criteria, totaling the study sample and being included for analysis.

The study was carried out following the ethical recommendations of Resolution 466/2012 of the National Health Council. The research was approved by the
Comitê de Ética em Pesquisa da Universidade Federal do Ceará (Research Ethics Committee of the Federal University of Ceará), under opinion 699.599 and CAAE 85767218.1.0000.5045.

\section{RESULTS}

Most of the research participants were female (57.7\%; $60)$. The age ranged from 24 to 87 years, with an average of $58 \pm 14$ years of age. There was a predominance of married or in a stable relationship (44.2\%; 46), with elementary education $(53.8 \% ; 56)$ and family income of one to two minimum wages $(64.4 \% ; 67)$ (Table 1 ).

Approximately 76\% (80) of the research participants were not engaged in paid work at the time of the appointment, with the wound being the reason for leaving work activities in $46.2 \%$ (37) of the cases. It was found that $34.6 \%$ (36) received social security benefits due to the existence of VU.

The record of comorbidities was verified in 49 (47.1\%) medical records. Systemic arterial hypertension (SAH) and obesity were the most prevalent, respectively in $39.4 \%$ (41) and $18.3 \%$ (19) of the participants. The presence of two comorbidities was found in $18.3 \%$ (19) and the presence of three or more comorbidities in $15.4 \%$ (16), the most common association being $\mathrm{SAH}$ and diabetes mellitus $(10.6 \% ; 11)$ (Table 2).

Regarding the use of medication, $67.3 \%$ (70) used some type of medication at the time of the consultation. The most used drug classes were antihypertensive drugs with $25 \%$ (26) and analgesics and anti-varicose drugs with $17.3 \%$ (18) each.

Most individuals had a single ulcer $(78.8 \% ; 82)$, located predominantly in the malleolar region $(33.6 \%$; 35). The lesion area ranged from 0.25 to $510 \mathrm{~cm}^{2}$, with a median of $17.1 \mathrm{~cm}^{2}$ and interquartile range from 5 to $44 \mathrm{~cm}^{2}$, the majority with an area of injury greater than $20 \mathrm{~cm}^{2}(31,7 \%$; 33). The time of existence of VU ranged from 1 month to 46 years, with injuries more than 10 years old $(31.7 \%$; 33$)$ being more common (Table 3$)$.

More than 92\% (96) of people with VU performed the dressing change at home, using mainly saline (77.0\%; 74) for cleaning the wound, followed by soap and water $(11.5 \%$; $11)$; in the other medical records $(11.5 \% ; 11)$ there was no record about the product used to clean the wound. 
Table 1. Sociodemographic characteristics of people with venous ulcers in outpatient care at a university hospital. Fortaleza (CE), Brazil - 2015 to 2018.

\begin{tabular}{|c|c|}
\hline Gender & n (\%) \\
\hline Female & $60(57,7)$ \\
\hline Male & $44(42,3)$ \\
\hline Marital status & n (\%) \\
\hline Married/Stable relationship & $46(44,2)$ \\
\hline Divorced & $5(4,8)$ \\
\hline Single & $35(33,7)$ \\
\hline Widowed & $18(17,3)$ \\
\hline Age range & n (\%) \\
\hline 24 to 39 years & $9(8,7)$ \\
\hline 40 to 59 years & $48(46,1)$ \\
\hline 60 years or more & $47(45,2)$ \\
\hline Education & n (\%) \\
\hline Illiterate / Functional illiteracy & $16(15,4)$ \\
\hline Elementary School & $56(53.8)$ \\
\hline High school & $24(23.0)$ \\
\hline Higher education & $3(3.0)$ \\
\hline No registry & $5(4.8)$ \\
\hline Family income & n (\%) \\
\hline Up to a minimum wage & $24(23.1)$ \\
\hline One to two minimum wages & $67(64.4)$ \\
\hline Three to four minimum wages & $10(9.6)$ \\
\hline No registry & $3(2.9)$ \\
\hline Exercise of paid activity & n (\%) \\
\hline Yes & $24(23.1)$ \\
\hline No & $80(76.9)$ \\
\hline
\end{tabular}

Table 2. Comorbidities and medications used by people with venous ulcers in outpatient care at a university hospital. Fortaleza (CE), Brazil - 2015 to 2018.

\begin{tabular}{|c|c|}
\hline Comorbidities & n (\%) \\
\hline Systemic arterial hypertension & $41(39.4)$ \\
\hline Obesity & 19 (18.3) \\
\hline Diabetes Mellitus & $17(16.3)$ \\
\hline Alcoholism & $13(12.5)$ \\
\hline Heart disease & $10(9.6)$ \\
\hline Dyslipidemia & $8(7.7)$ \\
\hline Nephropathy & $4(3.8)$ \\
\hline Coagulation disorders & $4(3.8)$ \\
\hline Others* & $9(8.6)$ \\
\hline No registry & $55(52.9)$ \\
\hline Medicines & n (\%) \\
\hline Antihypertensive drugs & $26(25.0)$ \\
\hline Pain relievers & $18(17.3)$ \\
\hline Anti varicose & 18 (17.3) \\
\hline Antibiotics & $9(6.7)$ \\
\hline Anti-inflammatories & $9(6.7)$ \\
\hline Hypoglycemic & $7(8.6)$ \\
\hline Hypolipidemic & $7(8.6)$ \\
\hline $\begin{array}{l}\text { Anticoagulants / } \\
\text { Antiplatelet agents }\end{array}$ & $4(3.8)$ \\
\hline Others** & $27(26.0)$ \\
\hline No registry & $34(32.7)$ \\
\hline
\end{tabular}

* Osteoporosis (3), rheumatoid arthritis (1), kidney transplant (1), hypothyroidism (1), uterine myoma (1); ** Diuretics, antiulcerative, glucocorticoid, immunosuppressant. 
Table 3. Characteristics of venous ulcers in outpatients at a university hospital. Fortaleza (CE), Brazil - 2015 to 2018.

\begin{tabular}{|c|c|}
\hline Number of ulcers & $\mathrm{n}(\%)$ \\
\hline One & $82(78.8)$ \\
\hline Two & $17(16.3)$ \\
\hline Three & $3(2.9)$ \\
\hline Four & $2(2.0)$ \\
\hline Location of ulcers & $\mathrm{n}(\%)$ \\
\hline Malleolus & $26(25.0)$ \\
\hline Distal third of the leg & $18(17.3)$ \\
\hline RLL or LLL registration only & $18(17.3)$ \\
\hline Middle third of the leg & $9(6.7)$ \\
\hline Foot & $9(6.7)$ \\
\hline Medial + distal third & $7(8.6)$ \\
\hline Distal third + foot & $2(1.9)$ \\
\hline Malleolus + foot & $2(1.9)$ \\
\hline Proximal third of the leg & $1(1.0)$ \\
\hline Calcaneous & $1(1.0)$ \\
\hline No registry & $8(7.7)$ \\
\hline Ulcer area & $\mathrm{n}(\%)$ \\
\hline Less than $5 \mathrm{~cm}^{2}$ & $17(16.4)$ \\
\hline$\geq 5$ to $10 \mathrm{~cm}^{2}$ & $10(9.6)$ \\
\hline$\geq 10$ to $15 \mathrm{~cm}^{2}$ & $5(4.8)$ \\
\hline$\geq 15$ to $20 \mathrm{~cm}^{2}$ & $6(5.8)$ \\
\hline Larger than $20 \mathrm{~cm}^{2}$ & $33(31.7)$ \\
\hline No registry & $33(31.7)$ \\
\hline Ulcer time & $\mathrm{n}(\%)$ \\
\hline Under 1 year & 18 (17.3) \\
\hline$\geq 1$ to 5 years & 25 (24.0) \\
\hline
\end{tabular}

continue...
Table 3. Continuation...

\begin{tabular}{|c|c|}
\hline Ulcer time & n (\%) \\
\hline$\geq 5$ to 10 years & $21(20.2)$ \\
\hline$\geq 10$ years & $33(31.7)$ \\
\hline No registry & $7(6.8)$ \\
\hline $\begin{array}{l}\text { Coverings used on an } \\
\text { outpatient basis }\end{array}$ & $\mathrm{n}(\%)$ \\
\hline Unna boot & $69(66.3)$ \\
\hline Activated carbon with silver & $7(6.7)$ \\
\hline Collagenase & $7(6.7)$ \\
\hline $\begin{array}{l}\text { Oil based on essential } \\
\text { fatty acids }\end{array}$ & $6(5.9)$ \\
\hline Hydrofiber with silver & $5(4.8)$ \\
\hline Hydrogel & $5(4.8)$ \\
\hline Calcium alginate & $2(1.9)$ \\
\hline Hydrocolloid & $2(1.9)$ \\
\hline PHMB gel & $1(1.0)$ \\
\hline
\end{tabular}

$M I D=$ membro inferior direito; $\mathrm{MIE}=$ membro inferior esquerdo; $\mathrm{PHMB}$ $=$ polihexanida

Among the people investigated, only nine reported using some primary coverage to perform the dressing at home. The products mentioned were: essential fatty acids (EFA), collagenase, barbatimão healing ointment, silver sulfadiazine and mineral oil. Only 36 (34.6\%) reported adhering to compression therapy, using an elastic band or compression stockings.

In an outpatient setting, the Unna boot, inelastic compression therapy, was the most used coverage for the treatment of injuries $(66.3 \% ; 69)$, followed by activated charcoal with silver $(6.7 \% ; 7)$, collagenase $(6,7 \% ; 7)$ and EFA-based oil (5.9\%; 6) (Table 3).

No coverage was found for four instruments. However, the use of more than 100 products was accounted for, due to the association of some of them, such as EFA-based oil and hydrogel, EFA-based oil and collagenase, activated carbon with silver and Polyhexanide (PHMB) gel, Unna boot and silver activated carbon. 
Regarding involvement in wound care at home, records were found in 95 instruments, with the person with VU being the main person involved in direct wound care in $63.2 \%$ (60) of the cases. The assistance of children was verified in $20 \%$ (19) of the cases, followed by the care provided by spouses $(9.5 \%$; 9 ) and other people, such as brothers-in-law, brothers, nephews and health professionals $(7.4 \% ; 7)$.

\section{DISCUSSION}

Studies show a higher prevalence of $\mathrm{VU}$ in women ${ }^{9-11}$. However, despite the higher prevalence in the female group, studies do not show statistical significance between the occurrence of the wound and the sexual gender.

Low education and low income are socioeconomic characteristics common to people with VU monitored in the public health system, being corroborated by other researches in the national scenario ${ }^{11-13}$.

The incidence of $\mathrm{VU}$ increases with advancing age, occurring more frequently in the middle-aged and elderly group ${ }^{9-12}$.Due to the inherent physiological changes, such as lower immunological intake, decreased muscle tone and greater fragility of the skin and the accumulation of comorbidities, aging is a predisposing factor for the occurrence of skin lesions.

Hypertension was the most prevalent comorbidity and its association with diabetes mellitus the most common combination. This finding is common to other studies in different contexts ${ }^{10,12,13}$. Hypertension, dyslipidemia and diabetes mellitus associated with advanced age favor the onset of microvascular disease, with impairment of endothelial function, leading to a progressive decrease in vascular flow. This mechanism favors the creation of an ischemic microenvironment for tissues, with consequent delay in tissue repair, since inflammatory activity and tissue synthesis are oxygen-dependent $\mathrm{t}^{10,14}$.

In people with diabetes the healing process is slowed down. Some mechanisms identified as important factors for delayed healing are: excessive production of reactive oxygen species (ROS), decreased nitric oxide (NO) and decreased response to growth factors. Excessive ROS production is a primary factor that contributes to impaired healing. $\mathrm{NO}$ reduction impairs angiogenesis and cell mobilization to the wound bed ${ }^{12}$.
In an integrative review conducted by Almeida et al. (2016) the influence of drugs on the formation of pressure lesions was verified, which can be explained by the systemic changes that cause reactions in the human organism. In this sense, the use of medication may contribute to delay the healing of VU, due to systemic changes and adverse effects caused by continuous use.

The use of anti-inflammatory drugs slows down the inflammatory response of the first stage of the healing process. Antihypertensive drugs alter tissue perfusion and may have some adverse effects, such as skin rash and peripheral vasoconstriction. These drugs plus painkillers and antibiotics have been described by research as common in people with pressure injuries ${ }^{12}$.

In this study, ulcers were located mainly in the distal leg and malleolar region. A common fact in other studies on the subject and already consolidated in the literature ${ }^{9-12}$. In some circumstances, $\mathrm{VU}$ may occur in the upper part of the calf or feet, but in these situations other etiologies of chronic ulcers should be excluded before attributing the venous etiology $\mathrm{y}^{2,13}$.

The Unna boot was the most used therapy on an outpatient basis for the treatment of the wound. It is an inelastic bandage impregnated with zinc oxide-based paste, which helps in venous return and in the reduction of edema, while providing a moist environment that favors the healing process ${ }^{2,13}$.

Other primary coatings, such as calcium alginate and silver hydrofiber are used to assist in the control of exudate, with silver coatings (hydrofiber and activated carbon) used for the prevention and / or control of infection. The control of exudate favors granulation in the wound bed and avoids perilesion complications, such as maceration of edges and worsening of eczema, favoring the reduction of wound size and healing ${ }^{2,13}$.

Thus, the adequacy of the treatment used in the service with the recommendations of the literature for the treatment of VUs was verified, since compression therapy is considered the gold standard of treatment for ulcers of this etiology ${ }^{1}$. However, at home, there is low adherence to compression therapy by users, especially regarding the use of elastic bands and compression stockings.

It is worth mentioning that in public health services there is a great seasonality of products and materials used to assist people with injuries, due to bidding processes and auctions. In this sense, the availability 
of products and coverages is an important factor for the follow-up with the appropriate topical therapy, as well as the person's adherence to the treatment and follow-up in the service

The profile of low education and low income presented by the people monitored in the public service makes it difficult to purchase products and coverings for the treatment of the wound, leading them to use only what is available in the service. This can be verified by the small number of people who used bandages at home with the use of primary cover, as well as those who used socks or elastic bands as compression therapy.

This fact directly interferes with wound healing, since adequate therapy may not be available at the health service and may not be available to the person with a wound, due to low purchasing power. In this context, it is also necessary to consider the work process of health services, with overload of assistance due to the great demand for care. These intervening factors contribute to the chronicity of the wound, and can last for years, as well as for the increase of recurrent relapses.

People with VU have low adherence to compression therapy. Fact that may be related to failures in the health education process and guidance on compression therapy ${ }^{13}$.

In addition, the climatic factor is also an important point that must be taken into account for adherence to compression therapy. In warmer environments the heat contributes to increase the thermal sensation, causing discomfort and increasing the humidity in the place which, together with the exudate proper to the wound, contributes to the occurrence of maceration of the edges and perilesion complications, such as dermatitis. To minimize these effects, it would be necessary to increase the frequency of coverage changes, however, this is not always feasible due to the low availability of material and human resources.

The presence of an effective support network, such as the help of a partner or family member, is an important ally for caring for VUs, as it helps in facing difficulties and acts as a facilitating agent in the treatment process, which can positively influence adherence to appropriate conducts ${ }^{3,10}$.

Due to changes inherent to aging, such as reduced bone density, muscle mass and strength, as well as a progressive decrease in visual and auditory acuity, the elderly person has greater fragility and difficulties to perform some daily activities $^{13}$. In this sense, the performance of the dressing itself by the elderly is not such a simple task to be performed and can contribute to the greater risk of imbalance and falls. The presence of a family member or caregiver when performing the dressing is important, as it helps in better performing the procedure, as well as reducing the risk of falls and other accidents to which the elderly are exposed when alone.

Adherence to treatment is one of the factors responsible for significantly reducing the healing time and decreasing recurrences. It is believed that the main reason for relapses is the individual's non-adherence to preventive measures (use of compression therapy, elevation of lower limbs and regular exercise) due to lack of knowledge, difficulties in assimilating information or failure in orientation ${ }^{13,14}$.

Follow-up with a multidisciplinary team after the ulcer heals is an important strategy for maintaining quality of life and preventing recurrences. Periodic assessment of skin conditions, assessment of surgical correction of incompetent veins, as well as health education activities that encourage adherence to compression therapy and other self-care actions contribute to reducing ulcer recurrence ${ }^{11}$.

The profile of the person with VU treated by the public health system Sistema Único de Saúde - SUS - (old age, low income and low education) can interfere negatively in the wound healing process due to the greater difficulty in relation to learning and understanding the orientations received. Health literacy, understood as the person's competence to understand and apply health information to judge and make decisions in daily life about health care, in order to maintain or improve aspects of life ${ }^{14}$, it is also related to the ability to understand the information received and the consequent adherence to treatment.

In this sense, the role of nurses in the health education process is of fundamental importance, identifying the level of education and literacy of the person with a wound and the others involved in the care so that the guidelines about treatment are passed on appropriately to the level of the person's understanding. Thus, the chances of success in adhering to the proposed therapy are increased, with a consequent reduction in the healing time and decrease in the recurrence of wounds.

During the study, the main limitation found was the lack of information or registration of some items on the nursing consultation form. It was also verified that the printed matter went through improvements during the 
collection period, being evidenced prints with the presence or absence of items, as well as the formatting. This made it difficult to obtain the data, resulting in the non-use of some information in this research.

Despite the limitations presented, this study becomes important as it contributes to the dissemination of knowledge about the clinical profile of people with VUs in different contexts and regions of Brazil. It also provides a reflection on the assistance provided and the effectiveness of implemented interventions.

\section{CONCLUSION}

It is concluded that the profile of the person with VU that is part of this study is compatible with the profile presented by this population in other studies carried out in different contexts and in different regions of Brazil.
The delimitation of the profile of this population allows knowledge about the socio-cultural context to which they are inserted, as well as a reflection on the assistance provided and the effectiveness of the interventions implemented in the treatment of VU.

\section{AUTHORS ‘CONTRIBUTION}

Conceptualization: Oliveira AS e Alexandre SG; Methodology: Oliveira AS e Alexandre SG; Investigation: Oliveira AS; Correia DL e Vasconcelos KVP; Writing - First version: Oliveira AS e Alexandre SG; Writing - Review \& Editing: Oliveira AS; Alexandre SG; Silva FAA e Ferreira SL; Financing Acquisition: Oliveira AS; Correia DL; Vasconcelos KVP e Alexandre SG; Resources: Oliveira AS; Alexandre SG; Correia DL e Vasconcelos KVP; Supervision: Alexandre SG.

\section{REFERENCES}

1. Wounds International. Simplifying venous leg ulcer management. Consensus recommendations. Wounds Internacional 2015. [cited 2020 jan 22] Available at: https://www.woundsinternational.com/resources/details/ simplifying-venous-leg-ulcer-management-consensusrecommendations

2. Cardoso LV, Godoy JMP, Godoy MFG, Czorny RCN. Terapia compressiva: bota de Unna aplicada a lesões venosas: uma revisão integrativa da literatura. Rev Esc Enferm USP 2018; 52:e03394. https://doi.org/10.1590/S1980$220 \times 2017047503394$

3. Joaquim FL, Silva RMCRA, Garcia-Caro MP, Cruz-Quintana F, Pereira ER. Impact of venous ulcers on patients' quality of life: an integrative review. Rev Bras Enferm 2018 July/ Aug;71(4):2021-9. https://doi.org/10.1590/0034-7167-20170516

4. Silva TG, Vasconcelos APL, Ramos EVC, Farias Neto JP. Avaliação da qualidade de vida de pacientes portadores de feridas crônicas atendidos no ambulatório de cicatrização do Hospital Universitário de Sergipe. R bras Qual Vida 2017 jul/set;9(3):234-46. https://doi.org/10.3895/rbqv.v9n3.6704

5. Wojastyk LDMC, Paula MAB, Prado MNB. Estomaterapia: influências e repercussões na carreira profissional. ESTIMA Braz J Enterostomal Ther 2020;18:e2020. https://doi. org/10.30886/estima.v18.883_PT
6. Borges EL, Ferraz AF, Carvalho DV, Matos SS, Lima VLAN. Prevenção de recidiva de úlcera varicosa: um estudo de coorte. Acta Paul Enferm 2016 jan/fev;29(1):9-16. https:// doi.org/10.1590/1982-0194201600003

7. Teixeira AKS, Silva LF, Marques ADB, Soares CRS. Caracterização de pacientes com úlcera venosa assistidos em ambulatório de estomaterapia de hospital público. ESTIMA Braz J Enterostomal Ther 2018;16:e0318. https:// doi.org/10.30886/estima.v16.346_PT

8. Cruz CC, Caliri MHL, Bernardes RM. Características epidemiológicas e clínicas de pessoas com úlcera venosa atendidas em unidades municipais de saúde. ESTIMA Braz J Enterostomal Ther 2018;16:e1218. https://doi. org/10.30886/estima.v16.496

9. Souza FJ, Aquino JFST, Silva MAG, Oliveira MF, Dantas SRPE. Medidas não invasivas de prevenção da recidiva de úlcera venosa: revisão integrativa. ESTIMA Braz J Enterostomal Ther 2019;17:e1119. https://doi.org/10.30886/estima. V17.713_PT

10. Liberato SMD, Araújo RO, Souza AJG, Marconato AMP, Costa IKF, Torres GV. Adesão ao tratamento de pessoas com úlceras venosas atendidas na atenção primária à saúde. Aquichan 2017;17(2):128-39. https://doi.org/10.5294/ aqui.2017.17.2.2 
11. Oliveira MF, Viana BJF, Matozinhos FP, Silva MMS, Pinto DM, Moreira AD et al. Feridas em membros inferiores em diabéticos e não diabéticos: estudo de sobrevida. Rev Gaúcha Enferm 2019;40:e20180016. https://doi. org/10.1590/1983-1447.2019.20180016

12. Gamba MA, Petri V, Costa MTF. Úlceras venosas, arteriais e mistas. In: Feridas: Prevenção, Causas e Tratamento. Rio de Janeiro: Santos; 2016. p.263-69.
13. Cavalcante VMV, Alexandre SG, Silva FAA, Santiago JCS, Coelho MMF, Avelino BMA et al. Socioeconomic and clinicalepidemiological profile of people attended in an outpatient clinic for complex wounds. Rev Rene 2020;21:e43918. https://doi.org/10.15253/2175-6783.20202143918

14. Almeida AFS, Soares TSB, Abreu RNDC, Mendonça FAC, Guanabara MAO, Sampaio LRL. Influência de fármacos sobre a formação de úlceras por pressão. Rev Enferm Contemp 2016 jan/jun;5(1):118-24. https://doi.org/10.17267/23173378rec.v5i1.681 